\title{
Disentangling the Frames, the State of Research on the Alphavirus 6K and TF Proteins
}

\author{
Jolene Ramsey (D) and Suchetana Mukhopadhyay * \\ Department of Biology at Indiana University, Bloomington, IN 47405, USA; jolramse@indiana.edu \\ * Correspondence: sumukhop@indiana.edu
}

Academic Editors: Beate M. Kümmerer and Tero Ahola

Received: 17 June 2017; Accepted: 16 August 2017; Published: 18 August 2017

\begin{abstract}
For 30 years it was thought the alphavirus $6 \mathrm{~K}$ gene encoded a single $6 \mathrm{kDa}$ protein. However, through a bioinformatics search 10 years ago, it was discovered that there is a frameshifting event and two proteins, $6 \mathrm{~K}$ and transframe (TF), are translated from the $6 \mathrm{~K}$ gene. Thus, many functions attributed to the $6 \mathrm{~K}$ protein needed reevaluation to determine if they properly belong to $6 \mathrm{~K}, \mathrm{TF}$, or both proteins. In this mini-review, we reevaluate the past research on $6 \mathrm{~K}$ and put those results in context where there are two proteins, $6 \mathrm{~K}$ and TF, instead of one. Additionally, we discuss the most cogent outstanding questions for $6 \mathrm{~K}$ and TF research, including their collective importance in alphavirus budding and their potential importance in disease based on the latest virulence data.
\end{abstract}

Keywords: alphavirus; 6K; transframe; frameshifting; budding

\section{Introduction}

For 20 years, alphavirus researchers studied a 6 kilodalton protein aptly named $6 \mathrm{~K}$. This protein was identified to play a role in virus exit and was also determined to function as an ion channel. The $6 \mathrm{~K}$ protein was not required for virus infection. In 2008, a bioinformatics team discovered that what had been termed the $6 \mathrm{~K}$ protein was actually two proteins. A heptanucleotide slippery sequence within the $6 \mathrm{~K}$ gene directs ribosomal frameshifting and the consequent translation in the $(-1)$ open reading frame produces the transframe protein, or TF. The $6 \mathrm{~K}$ and TF proteins have identical N-termini, but unique $\mathrm{C}$-termini. When TF was identified, the accumulated literature was reevaluated to disentangle the results that applied specifically to $6 \mathrm{~K}$, to $\mathrm{TF}$, or to both. Within the last nine years, several reports have emerged addressing the specific activities of TF and $6 \mathrm{~K}$. Here we address the current state of our knowledge about $6 \mathrm{~K}$ and TF and explore the most cogent questions remaining to determine their function in an alphavirus infection.

\section{The Assembly-Centric Alphavirus Lifecycle}

Classified within the Togaviridae family, the Alphaviruses are enveloped particles transmitted by arthropods ([1] and references therein). Virions are $\sim 70 \mathrm{~nm}$ in diameter. The viral lipid bilayer contains 240 copies each of two envelope glycoproteins, E2 and E1, forming an exterior proteinaceous shell. Beneath the bilayer is a second protein shell called the nucleocapsid core. Both the exterior glycoproteins and the interior core have $\mathrm{T}=4$ icosahedral symmetry. The nucleocapsid core protein surrounds a single copy of the single-stranded, capped, and polyadenylated $\sim 12$ kilobase RNA genome. Depending on the alphavirus species, the viral proteins E3, 6K, or TF may also be present in the virion, but these are not required for the particle to be infectious [1]. Host molecules are generally absent in wild-type (WT) virus, though ribosomal components have been shown to be packaged within the core [2]. 
As arboviruses, alphaviruses are generally transmitted in the environment via an arthropod vector (typically a mosquito) to vertebrate hosts which can include birds, humans, and other mammals [3]. In the laboratory, alphaviruses can replicate efficiently in small animal models and various host-derived cell lines. Most animals experience a high-morbidity, low-mortality infection, but this varies by alphavirus species. At the cellular level, arthropod host cells typically experience a persistent infection, while vertebrate cells expire after an acute infection [4].

To infect host cells, the E2 glycoprotein on the virion binds to host cell surface receptors [1]. Following endocytosis, a low-pH mediated conformational change in E1 activates it to mediate fusion between the host membrane and virus membrane. Translation begins immediately upon delivering the positive-sense RNA genome into the cytoplasm of a host cell. The first open reading frame codes for the nonstructural proteins. The four nonstructural proteins function in RNA replication and modulation of the host response. For an in-depth description of RNA replication functions, we refer readers to a recent review by Rupp and colleagues [5]. A review by Fros and Pijlman describes our current understanding of the interplay between virus takeover and host cell responses [6]. The host cell responses are countered in a vertebrate cell infection by a rapid shutoff of host cell protein production that can be mediated by nonstructural protein 2 or the structural protein capsid [7-9].

The virus structural proteins are all translated as a polyprotein from the second open reading frame on a subgenomic RNA transcript [1] (Figure 1A). To understand the consequences of translating $6 \mathrm{~K}$ versus $\mathrm{TF}$, it is necessary to understand how the structural proteins are translated, translocated into the endoplasmic reticulum (ER), cleaved, and then oligomerized to form functional assembly components. The capsid protein is translated, folded in the cytoplasm, and then cleaved in cis via its chymotrypsin-like domain from the rest of the polyprotein [10-12]. The capsid protein encapsidates newly synthesized viral RNA to form nucleocapsid cores in the cytoplasm. The E3 protein is translated after the capsid protein, and contains the signal sequence that directs the remainder of the polyprotein translation to the ER membranes (Figure 1B,C). The polyprotein traverses the ER membrane several times. The E2 protein is translated with two transmembrane domains, containing the translocon signal for $6 \mathrm{~K}$. The $6 \mathrm{~K}$ protein is thought to have two transmembrane helices connected by a short cytoplasmic loop (Figure 1B). The second helix in $6 \mathrm{~K}$ is the translocation signal for E1, usually the last protein to be translated. The E1 protein has a single transmembrane domain, leaving a short cytoplasmic C-terminal tail. When frameshifting in the $6 \mathrm{~K}$ gene occurs, the $\mathrm{E} 3$ and E2 proteins are produced as described above. However, rather than two transmembrane helices in 6K, the TF protein's unique C-terminus is translated into the cytoplasm and no E1 is made (Figure 1C). Using radioisotope labeling, antibodies, and mass spectrometry to detect TF, it is estimated that frameshifting occurs $<30 \%$ of the time [13-16]. The consequence of translating E2 but not E1 due to the frameshifting event is not understood.

After the structural proteins are translated, they undergo conformational maturation and localization to become assembly-competent. Cellular enzymes cleave the structural polyprotein into its individual constituents (Figure 1B,C). Signalase cleaves E1 from $6 \mathrm{~K}$, and E2 from $6 \mathrm{~K}$ and $\mathrm{TF}[17,18]$. As a result, the second transmembrane domain of $\mathrm{E} 2$ is released from the membrane into the cytoplasm. The E3 protein remains covalently attached to E2 and aids with cellular chaperones in the proper folding of E2 and E1 [19-24]. While in the ER, E3 + E2 (also called pE2 in the literature) and E1 associate into heterodimers. Those heterodimers trimerize into complexes called spikes [25,26]. Glycosylation moieties are added to E3, E2, and E1 and subsequently modified as the spikes transit through the secretory system to the plasma membrane. The cellular protease furin cleaves E3 from E2 in the trans-Golgi, making spikes fusion-competent $[27,28]$.

The last step before particle release is budding. Some enveloped viruses, e.g., human immunodeficiency virus I (HIV-I), require canonical host cell machinery (such as ESCRT—endosomal sorting complexes required for transport) to bud from cells $[29,30]$. Other enveloped viruses such as influenza encode their own budding protein [31,32]. Alphaviruses use an ESCRT-independent mechanism for budding, but it is not known if other host proteins are required or if a viral protein aids in budding [31,32]. Two models proposed for alphavirus budding are: (1) budding is driven by 
an association between viral glycoproteins followed by interactions with the capsid and RNA, and (2) preformed nucleocapsid cores drive interactions between glycoproteins that result in budding. Specifically, it has been shown that three amino acid residues in the cytoplasmic tail of E2 (residues 400-402 in Sindbis) interact with a surface pocket on the capsid [33-35]. In multiple cell types, preformed cytoplasmic cores are observed interacting with spikes at interior sites, sometimes called cytopathic vacuoles (CPV-II) [36,37]. While the role of CPV-IIs in viral release is still being investigated, they are hypothesized to represent transport intermediates for viral components to the site of budding. In arthropod cells, budding is observed at internal membranes, while this usually occurs at the plasma membrane from vertebrate cells [37-39]. The mechanism of alphavirus budding is not known but studies (see below) have attributed defects in assembly and budding to mutations in the $6 \mathrm{~K}$ gene.

\section{A}

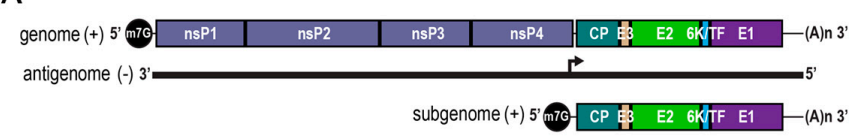

B

$6 \mathrm{~K}$ polyprotein pre-cleavage $\quad 6 \mathrm{~K}$ polyprotein post-cleavage

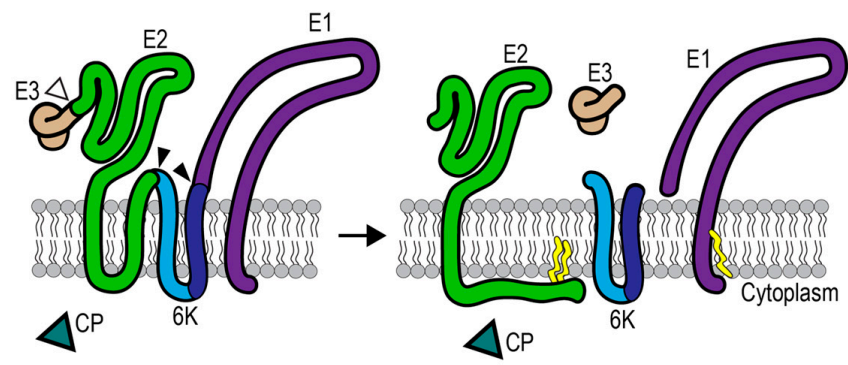

C

TF polyprotein pre-cleavage TF polyprotein post-cleavage

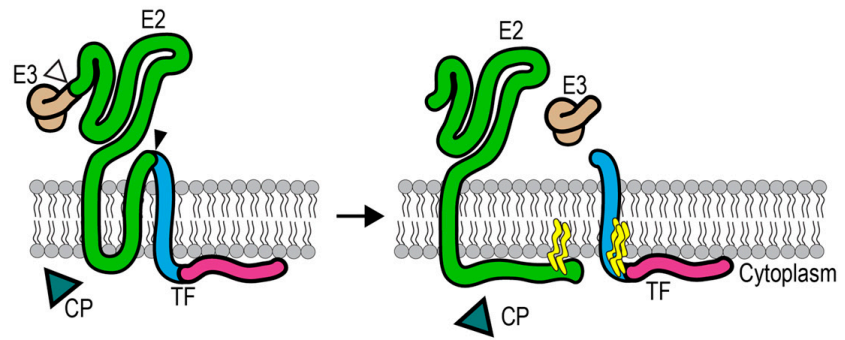

Figure 1. Structural polyprotein membrane topology and processing. (A) The positive-sense RNA alphavirus genome has two open reading frames. At the 5' end is the methyl-7-guanosine cap (m7G), followed by the nonstructural protein $(\mathrm{nsP})$ and structural protein open reading frames, and the 3' poly A tail. Nonstructural proteins are translated directly from the genome. During replication, the minus-sense antigenome is used as the template for producing the subgenomic RNA from an internal subgenomic promoter (arrow). Structural proteins are translated from the subgenomic transcript. (B,C) Pre-cleavage structural polyprotein conformation in the endoplasmic reticulum (ER) membrane. Capsid (CP) is first released as a soluble protein in the cytoplasm. The N-terminus of E3 contains a signal sequence that directs translocation across the membrane. Open arrows mark the furin cleavage site between E3 and E2, which occurs in the trans-Golgi network. The remaining envelope proteins are threaded through the membrane with insertion of transmembrane domains. Closed arrows mark signalase cleavage sites that are used in the ER. Post-cleavage conformations include palmitoylation sites (yellow). (B) The 6K polyprotein is the majority translation product. (C) The TF form of the polyprotein is the minority product resulting from frameshifting in the $6 \mathrm{~K}$ gene, and does not include E1. 


\section{Enter TF, the Other $6 \mathrm{~K}$}

In 2008, Firth and colleagues bioinformatically predicted and experimentally demonstrated that the $6 \mathrm{~K}$ gene actually produces two distinct protein products, $6 \mathrm{~K}$ and TF [14]. This occurred via a $(-1)$ ribosomal frameshift site that is highly conserved across the alphaviruses. Indeed, all the sequenced alphavirus genomes to date contain a heptanucleotide slip site that is essential for the production of TF [14,40-42], and TF production has been demonstrated experimentally in Semliki Forest (SFV), Sindbis (SINV), Chikungunya (CHIKV), and Salmon pancreatic disease virus [14-16,43]. In Venezuelan equine encephalitis virus (VEEV), natural variants missing portions of $6 \mathrm{~K}$, often losing the TF slip site, were detected by deep sequencing [44]. Additionally, among the fish alphavirus family, natural variants have been isolated with deletions in $6 \mathrm{~K}$ [45]. The genomes with $6 \mathrm{~K}$ deletions have been shown to recombine in animal hosts to reincorporate the $6 \mathrm{~K}$ gene when it is available from a heterologous template [43,46]. Overall though, the genetic capacity to produce the TF protein from the $6 \mathrm{~K}$ gene via frameshifting is nearly universally present among the alphaviruses.

Frameshifting in viruses is well-studied in the classic case of the retroviruses where the Pol open reading frame is in the (-1) reading frame relative to Gag upstream [47-49]. Many viruses use frameshifting as a strategy to maximize their coding potential (recently reviewed in [50,51]). What we understand for the alphaviruses is that as the ribosome translates the $6 \mathrm{~K}$ message, it encounters a heptanucleotide slip site about two-thirds of the way through the gene, followed by a poorly defined spacer and then a stable secondary structure that varies between viruses $[52,53]$. One investigation used a dual luciferase reporter to measure the frameshifting rates induced by alphavirus signals that were predicted to fold into RNA secondary structures including stem loops, hairpins, and pseudoknots [52]. The dual luciferase reporter has allowed investigation into additional species beyond the prototype alphaviruses, including Middelburg, sleeping disease, southern elephant seal, and Getah viruses. The range reported for these disparate alphaviruses ranges from 1\% to $48 \%$ [52]. Although the rates varied, in the New World alphaviruses VEEV, eastern equine encephalitis virus, and western equine encephalitis virus, the tandem stem loop stimulatory signals downstream were confirmed, and also found to not be controlled by miRNA [53]. At a low frequency, these signals can stimulate the ribosome to slip backwards by one nucleotide into the $(-1)$ reading frame, and then translation continues in the new frame to produce the TF protein, resulting in a unique C-terminus from that of $6 \mathrm{~K}$. E1 is not translated when TF is produced.

The $6 \mathrm{~K}$ and TF proteins each contain an identical N-terminal transmembrane domain and a short cysteine-rich cytoplasmic loop prior to their unique C-terminal ends (Figure 2). As integral membrane proteins, $6 \mathrm{~K}$ and TF are both found in membranous fractions of cells, and extract with anionic (SDS and sodium deoxycholate), nonionic (Nonidet ${ }^{\mathrm{TM}}$ P-40, IGEPAL ${ }^{\circledR}$ CA-630, and Triton X-100), and zwitterionic (CHAPS-3-((3-cholamidopropyl) dimethylammonio)-1-propanesulfonate) detergents from eukaryotic and bacterial cells $[14,16,43,54-56]$. Apart from conserved hydrophobic membrane segments, the N-terminus also maintains several conserved residues (shown in Figure 2), and two or more cysteine residues prior to the slip site. The C-terminal domain of $6 \mathrm{~K}$ is thought to be a second transmembrane domain, and the C-terminus of TF appears to be a hydrophilic cytoplasmic extension. The length of TF after the slip site varies by alphavirus from a predicted seven amino acids long in Aura virus to 46 amino acids long in the fish alphaviruses, and no striking conservation is noted. 
A: $6 \mathrm{~K}$ amino acid alignment

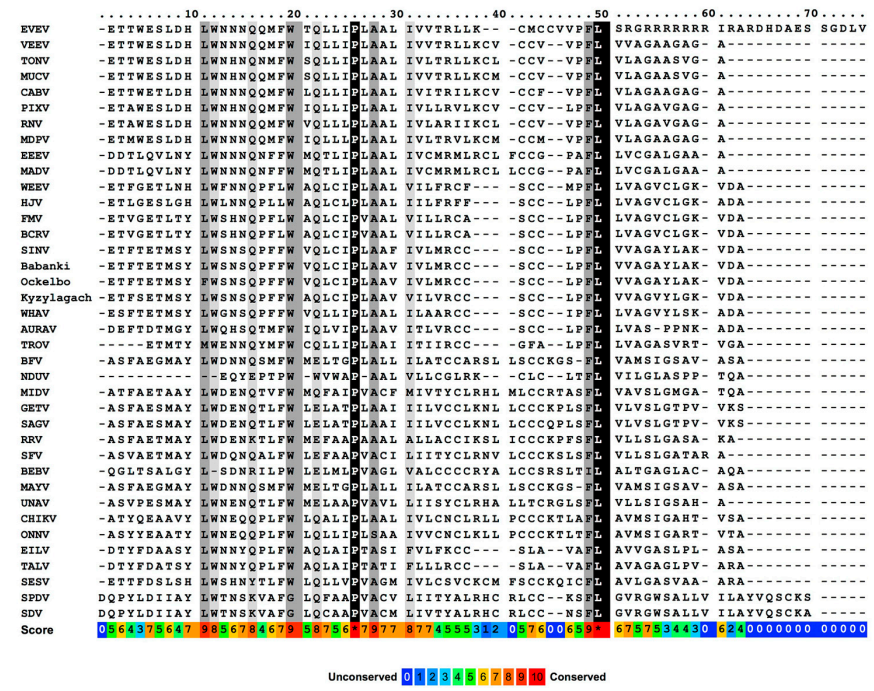

B: TF amino acid alignment

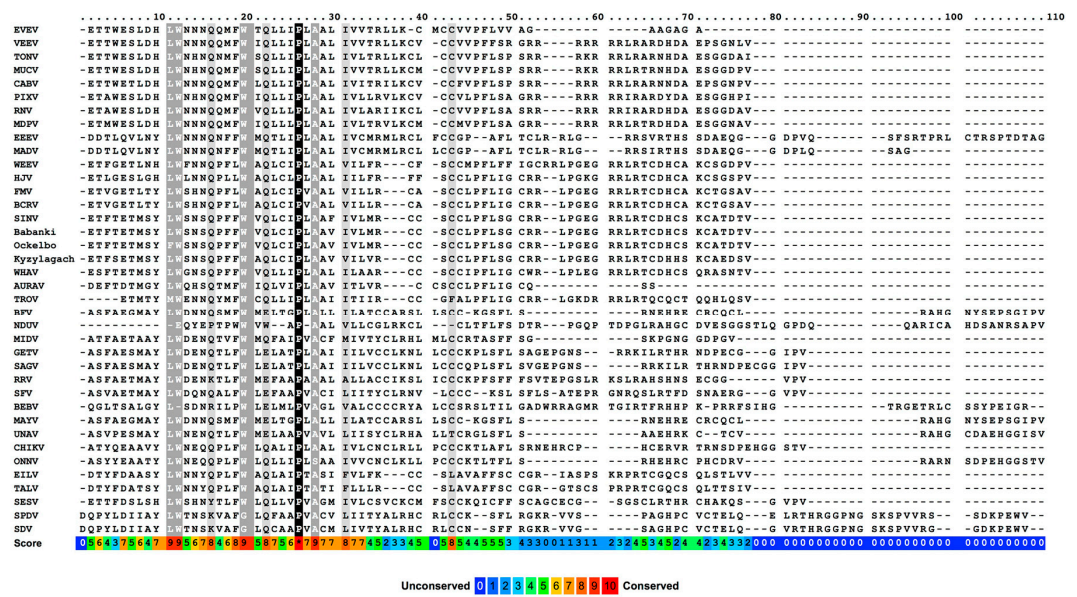

Figure 2. Multiple sequence alignment of (A) $6 \mathrm{~K}$ and (B) TF with representatives from all International Committee on the Taxonomy of Viruses [57] recognized alphavirus species, and the newly discovered Taï Forest virus [42]. Sequences were retrieved from GenBank [58] with the accession numbers that follow. The $6 \mathrm{~K}$ and TF translations were then aligned with the online PRALINE multiple sequence alignment program using the default parameters for homology-extended alignment [59-62]. The order in which the viruses are listed follows their relationships according to phylogeny, see [40]. The colored boxes across the bottom represent the consistency score (on a scale of $0-9{ }^{*}$ ), where blue is least conserved and red is most conserved. Scores of 8 or above are highlighted. Virus abbreviations and accession numbers are as follows: Everglades virus (AF075251) (EVEV); Venezuelan equine encephalitis virus (NC_001449) (VEEV); Tonate virus (AF075254) (TONV); Mucambo virus (AF075253) (MUCV); Cabassou virus (AF075259) (CABV); Pixuna virus (AF075256) (PIXV); Rio Negro virus (AF075258) (RNV); Mosso das Pedras virus (AF075257) (MDPV); eastern equine encephalitis virus (NC_003899) (EEEV); Madariaga virus (NC_023812) (MADV); western equine encephalitis virus (NC_003908) (WEEV); Highlands J virus (HM147988) (HJV); Fort Morgan virus (NC_013528) (FMV); Buggy Creek virus (HM147986) (BCRV); Sindbis virus (NC_001547) (SINV); SINV strain Babanki virus (HM14798); SINV strain Ockelbo virus (M69205); SINV strain Kyzylagach virus (AF339478); Whataroa virus (HM147993) (WHAV); Aura virus (NC_003900) (AURAV); Trocara virus (HM14799) (TROV); Barmah Forest virus (NC_001786) (BFV); Ndumu virus (HM147989) (NDUV); Middelburg virus (EF536323) (MIDV); Getah virus (NC_006558) (GETV); Sagiyama virus (AB032553) (SAGV); Ross River virus (DC5692) (RRV); Semliki Forest virus (NC_0032) (SFV); Bebaru virus (NC_016962) (BEBV); Mayaro virus (NC_003417) (MAYV); Una virus (AF339481) (UNAV); Chikungunya virus (YP_006491244) (CHIKV); O'nyong-nyong virus (M33999) (ONNV); Eilat virus (NC_018615) (EILV); Taï Forest virus (NC_032681) (TALV); southern elephant seal virus (HM147990) (SESV); salmon pancreas disease virus (AJ316244) (SPDV); sleeping disease virus (NC_003433) (SDV). 
Studies up to this point support that both the $6 \mathrm{~K}$ and TF proteins are important in budding, despite being nonessential in tissue culture. Recombinant viruses not producing $6 \mathrm{~K}$ and $\mathrm{TF}(\Delta 6 \mathrm{~K})$, producing only $6 \mathrm{~K}$ but not TF (6K-only, also called TF-null or $\triangle \mathrm{TF}$ ), and other TF mutants negatively impact infectious and total virus output from infected host cells compared to WT [13,15,55,63-65]. The absence of $6 \mathrm{~K}$ and TF in $\Delta 6 \mathrm{~K}$ reduces virus production by $10-100$ fold, and those virions also lack the structural integrity characteristic of WT particles $[16,63]$. TF is released in the virus particle while $6 \mathrm{~K}$ remains primarily at interior cell membranes $[14-16,66]$. Despite differences in experimental setup and somewhat varying results for different alphaviruses, it is clear that whether concentrated in the perinuclear ER/Golgi regions or the plasma membrane, $6 \mathrm{~K}$ and TF localize differently from each other $[13-16,66]$. Thus, the $6 \mathrm{~K}$ and TF proteins affect released virus particles by functioning inside the host cell where budding is initiated.

Several functions attributed to the $6 \mathrm{~K}$ protein have been experimentally determined. We will discuss these results in light of $6 \mathrm{~K}$ and TF both being present during an infection. In addition, we will discuss recent studies on the TF protein and summarize how these contribute to our understanding of virus assembly.

\section{Looking Back at the Discovery of the $6 \mathrm{~K}$ Protein}

The structural polyprotein's topology and orientation are critical for proper protein processing and function (Figure 1). Researchers studying the glycoproteins E2 and E1 were searching for the signal sequences responsible for their final membrane orientation detected at the surface of the virus. Studies in SINV and SFV quickly identified E3 as the insertion signal for E2 [67-69]. However, the signal for E1 had not yet been ascertained. E1 was a known Type I membrane protein, having its $\mathrm{N}$-terminus in the ER lumen and a short cytoplasmic tail following its transmembrane anchor domain $[4,70,71]$. Because the entire N-terminal ectodomain of $\mathrm{E} 1$ is found in the ER lumen, the protein immediately before it in the polyprotein would need to provide a start-transfer signal to translocate E1 into the ER lumen.

In 1979, a report by Welch and Sefton described two small polypeptides produced during SINV infection of vertebrate cells. In addition to the previously identified E3 protein, a new protein of 4200 daltons called $4.2 \mathrm{~K}$ was thought to represent the cleaved signal sequence for a glycoprotein [54]. The $4.2 \mathrm{~K}$ protein was not glycosylated, incorporated into virions, or released into the media. This same group then demonstrated an analogous protein of $6000 \mathrm{Da}$ was produced during SFV infection, and so named it $6 \mathrm{~K}$ for $6 \mathrm{kDa}$ [72]. Like the SINV 4.2K protein, the SFV $6 \mathrm{~K}$ protein was not glycosylated, present in mature virions, or released into the media. The authors concluded that the SINV $4.2 \mathrm{~K}$ and SFV $6 \mathrm{~K}$ proteins were analogous, and the field now refers to the $6 \mathrm{~K}$ gene product as the $6 \mathrm{~K}$ protein. N-terminal peptide sequencing suggested that the gene encoding $6 \mathrm{~K}$ was after E2 in the viral genome [73], and full-genome sequencing placed it unambiguously before E1 in the structural open reading frame $[17,74]$. When C-terminal segments of $6 \mathrm{~K}$ were shown to allow heterologous E1 translation, it strengthened the idea that $6 \mathrm{~K}$ functioned as the signal sequence for E1 [75,76].

The E2/6K and 6K/E1 junctions are cleaved by a host protease called signalase [11,77]. Signalase, a peptidase found in the ER lumen, was earlier hypothesized as one of two host proteins to process the alphavirus structural polyprotein $[17,18]$. Combined with a start transfer sequence found in the C-terminus of E2, this meant that both the $\mathrm{N}$ - and C-termini of $6 \mathrm{~K}$ were positioned in the ER lumen [77]. We now also know that when $6 \mathrm{~K}$ is deleted, the second hydrophobic stretch in E2 can serve as the start-transfer signal for E1, just as it does for 6K in a WT background [16,63,64].

How E1 translocates across the ER membrane into the lumen becomes irrelevant when TF is translated, however, because no E1 is translated. The lack of E1 production upon TF translation is interesting because there is no longer a 1:1 ratio between all the proteins encoded on the structural polyprotein. Various reports have suggested that in different cell lines, E1 and E2 are only stable and only make it to the cell surface if they associate in a 1:1 heterodimeric complex [78,79]. Low rates of TF translation could reflect that only a very small amount of TF is needed for its function. 
Low frameshifting rates could also reflect a need for maintaining a high amount of E1 translation for optimal spike assembly and low E2 misfolding levels.

\section{Posttranslational Modification in TF, but not 6K}

With both 6K termini in the ER lumen, it was immediately noticed that the short cytoplasmic connector loop was rich in cysteine residues. In the years before that, virus protein acylation, the covalent attachment of fatty acids to cysteine residues in proteins, had been demonstrated in alphavirus and rhabdovirus proteins [80-82]. Having seen that both E2 and E1 were modified by palmitoylation on cysteine residues [83-85], researchers next looked at the modifications on the $6 \mathrm{~K}$ protein.

An antibody generated against an amino acid sequence shared by the N-termini of both $6 \mathrm{~K}$ and TF immunoprecipitated two proteins from cells infected with SINV, one at $6 \mathrm{kDa}$ (most likely TF) and one at $4.2 \mathrm{kDa}$ (most likely 6K) [86]. Only the upper band was palmitoylated and budded into virions. From their experiments, they interpreted the results to mean their two bands were the same protein with different modification states. Phosphorylation and glycosylation were not present so the two bands were thought to represent alternatively palmitoylated $6 \mathrm{~K}$ proteins $[72,86]$. Their conclusions were logical since $6 \mathrm{~K}$ and TF have identical $\mathrm{N}$-termini. Based on this paradigm, the 2008 publication on TF came as a surprise. Follow-up studies on TF were consistent with the earlier results. The TF protein (or larger $6 \mathrm{~K}$ isoform), but not the $6 \mathrm{~K}$ protein (the smaller $4.2 \mathrm{~K}$ isoform), is palmitoylated on $\mathrm{N}$-terminal cysteines [16] and is predominantly present in released virions [14-16,86].

\section{Mutations that Control the Production of $6 \mathrm{~K}$ and TF during an Infection}

The $6 \mathrm{~K}$ became the first (and only) alphavirus gene to allow the recovery of an infectious virus after its deletion, demonstrating that $6 \mathrm{~K}$ is nonessential in tissue culture [63]. The $\Delta 6 \mathrm{~K}$ virions were more sensitive to thermal inactivation, but entry processes were not significantly altered compared to WT $[64,87]$. This did not, however, relegate $6 \mathrm{~K}$ as uninteresting because the $\Delta 6 \mathrm{~K}$ virus manifested budding defects. Transmission electron microscopy on $\Delta 6 \mathrm{~K}$-infected hamster cells revealed cores lined up beneath the plasma membrane, but very few budding particles, in contrast to the many budding particles seen in cells infected with WT. Additionally, the $\Delta 6 \mathrm{~K}$ virus yield from mammalian cell cultures is lower than WT at high growth temperatures [64]. These experiments support an accessory role for $6 \mathrm{~K}$ and/or TF during spike maturation, where they are not required for budding but enhance assembly, perhaps by stabilizing spikes.

In another study, researchers found a deletion in the $6 \mathrm{~K}$ gene had consequences for glycoprotein processing. Sanz et al. generated del-6K, a partial internal deletion from residues 24 to 45 in $6 \mathrm{~K}$, which ablates the frameshift site required for TF production and acts functionally as a clean $\Delta 6 \mathrm{~K}$ mutant [88]. The del-6K mutant was also found to have impaired glycoprotein processing, perhaps resulting from misfolding and improper spike assembly. A revertant found to alleviate the defect in del-6K was a single amino acid change, Q21L in $6 \mathrm{~K}$. These researchers attempted, unsuccessfully, to complement the partial deletion with a WT $6 \mathrm{~K}$, although the authors cautioned that having the protein out of context was an important caveat to their results.

In contrast, recent reports from salmonid alphaviruses (SAV) have shown that a $\Delta 6 \mathrm{~K}$ virus is nonviable [43]. The SAV $\Delta 6 \mathrm{~K}$ defect appears to be due to inappropriate glycoprotein processing and/or trafficking. Maturation of the E2 protein in SAV is temperature-sensitive in fish and other cell line cultures, and this sensitivity of E2 may be reflected in the failure to recover infectious virus in $\Delta 6 \mathrm{~K}[89,90]$. While in mammalian cells heterologous $6 \mathrm{~K}$ or TF expression does not rescue a deficiency, in SAV-infected cells the helper plasmid 6K expression does rescue virus infection $[15,43,88]$.

To analyze $6 \mathrm{~K}$ and TF contributions to budding separately, various groups have utilized a virus with several silent mutations in the conserved slip site region that abrogate frameshifting and produce only the $6 \mathrm{~K}$ protein. The $6 \mathrm{~K}$-only virus manifests a consistent delay in growth kinetics, but ultimately similar infectivity compared to WT is observed $[15,16,53]$. Since the $6 \mathrm{~K}$-only virus fares similarly to WT in tissue culture, it seems unlikely that TF is as critical for glycoprotein maturation as 6K. Furthermore, 
although TF is present in the WT virion, the published data do not support a spacer role for TF in the virion. TF protein remaining in the infected cell may function to exclude host proteins, corral spikes into the optimal budding conformation, or even interact with $6 \mathrm{~K}$.

\section{Evidence that $6 \mathrm{~K}$ Functions as a Spacer during Spike Assembly}

The 6K spacer hypothesis was proposed shortly after a full SFV genome clone was constructed and made available [91]. Cysteine mutants in the N-terminus of 6K (residues also present in TF) display budding defects, with both reduced virus release and altered morphology. The $6 \mathrm{~K} / \mathrm{TF}$ cysteine mutants bud multi-cored particles with multi-hit kinetics of thermal inactivation $[13,55,92]$. This multi-cored defect was also observed for a temperature-sensitive mutation in SINV E2 [93]. Connecting the similarity in phenotypes with the unpublished observation that a lysine in the $6 \mathrm{~K}$ protein can be crosslinked to the E2 tail cited in their paper, these authors postulated that an E2:6K protein interaction might be necessary for the $\mathrm{E} 2$ tail to interact with the capsid protein during budding. The cysteine $6 \mathrm{~K}$ mutants and a lysine mutant in $6 \mathrm{~K}$ were analyzed side by side with $\mathrm{E} 2$ mutations, and thus dawned the idea that $6 \mathrm{~K}$ is a spacer. Under this model, $6 \mathrm{~K}$ would aid in spike assembly and mediate the E2:CP interactions necessary for proper budding [55].

\section{Direct Evidence for a 6K:E2 Interaction in Glycoprotein Maturation}

Although a virus can bud without the $6 \mathrm{~K}$ and TF proteins, there are reports showing that $6 \mathrm{~K}$ interacts with the viral glycoproteins, perhaps prior to budding. In SFV, it was shown that $6 \mathrm{~K}$ could be co-precipitated from infected cells with antibodies that pull out heterodimer spike complexes, and surface-exposed glycoprotein complexes also co-precipitated 6K [94]. Subsequent studies have, however, supported a predominantly internal localization for $6 \mathrm{~K}[14-16,66,86]$. One study using electron microscopy has reported that $6 \mathrm{~K}$ may interact with intermediate filaments [95]. These experiments suggest a role for $6 \mathrm{~K}$ during or after spike transport to the plasma membrane.

How could the $6 \mathrm{~K}$ protein influence budding at the plasma membrane so dramatically from inside the cell? To investigate a potential direct interaction between the glycoproteins and $6 \mathrm{~K}$, Yao et al. used recombinant chimeric viruses that swapped in the Ross River virus (RRV) $6 \mathrm{~K}$ gene, or the $6 \mathrm{~K}: E 1$ gene pair, with the SINV genes in a SINV backbone [96]. The chimeric construct that swapped in $6 \mathrm{~K}$ alone, and keeping both E2 and E1 as a SINV sequence, would have a native RRV 6K, but for TF, a RRV sequence in the $\mathrm{N}$-terminus and SINV sequence in the C-terminus. This mutant virus had decreased budding and low E1 levels detected at the plasma membrane. The RRV 6K:E1 pair chimera in SINV, which would produce native RRV 6K and TF, was severely reduced in infectivity. Because E2 did not properly traffic to the plasma membrane, they proposed a sequence-specific interaction of $6 \mathrm{~K}$ with the glycoproteins to get them folded properly and to the plasma membrane [96]. However, it is known that SINV and RRV glycoproteins are not conserved enough that they can be exchanged and function normally without sequence adaptation [97,98]. More evidence for $6 \mathrm{~K}$ interacting with the glycoprotein transmembrane domains, in particular E2, came when a 39-amino-acid insertion into the RRV 6K gene of the RRV 6K in SINV chimera was isolated. The insertion, in combination with other mutations, recovered titer, while the addition of individual E2 point mutants within the transmembrane domain reduced the chimera's titer [99].

Additional studies on the E2 protein provided more evidence for direct interactions. London et al. screened for viable places to insert heterologous genes within the SINV E2 protein using a 13-amino-acid epitope [100]. During that process, they identified an insertion at residue 29 in the first transmembrane domain of 6K (6K29) [101]. The 6K29 mutant virions were indistinguishable from WT except that in the particle, they could not detect $6 \mathrm{~K}$ (which we now know is the TF protein). Further, $6 \mathrm{~K} 29$ was defective in host cell shutoff and glycoprotein processing was incomplete. Although entry steps were unaffected, they detected a trans-dominant negative effect on titer output in co-infections with WT [101]. In a follow-up study, they isolated a 6K29 revertant that showed increased neurovirulence [65]. The revertant contained two changes in the ectodomain of E2 (Q55H and H333Q). 
Further directed mutagenesis in the region corresponding to the transmembrane domain, specifically $6 \mathrm{~K} \mathrm{A28R}$, generated mutants defective in glycoprotein processing. A change of Ala 28 to Met corrected glycoprotein processing, but not particle budding defects. The multi-cored defect was alleviated by the addition of the $\mathrm{Q} 55 \mathrm{H}$ and $\mathrm{H} 333 \mathrm{Q} \mathrm{E} 2$ mutations [92]. Now that the TF protein has been identified, it is important to note that the insertions and other mutants isolated in these studies are in the shared $\mathrm{N}$-terminus and it is not possible to rule out effects from TF mutation here.

How would a potential interaction between $6 \mathrm{~K}$ and E2 affect particle budding? Since spike maturation is less efficient in $6 \mathrm{~K}$ mutants, particle release is compromised. Consistent with this observation, results from several studies have reported higher cell-associated virus titers for the SINV $6 \mathrm{~K} 29$ strain and the $\Delta 6 \mathrm{~K}$ virus in mammalian cells infected with SFV and RRV compared to WT $[64,66,101]$. The amount of cell-associated infectious virus reported in those studies can account for and sometimes exceed the reduction in media titer measured for $6 \mathrm{~K}$ mutant infections compared to WT. The cell-associated titer is hypothesized to represent intracellular budding or surface-associated virus. Internal budding is regularly observed for WT virus in mosquito cell infections [37,39]. These data suggest that a $6 \mathrm{~K}$ deficiency may simply route virus budding to an alternate exit pathway that is less efficient at release from mammalian cells. These functional budding defects in the $\Delta 6 \mathrm{~K}$ virus and the known effects on glycoprotein processing support the idea that an interaction between the glycoproteins and $6 \mathrm{~K}$ is important for budding.

\section{9. $6 \mathrm{~K}$ is a Viroporin}

Before TF was discovered, $6 \mathrm{~K}$ was also known to have a role beyond direct interactions with spike proteins to promote effective spike maturation as a modulator of membrane permeability. The $6 \mathrm{~K}$ protein is classified as a virus-derived ion channel, or viroporin [102]. Viroporins are usually small proteins with hydrophobic stretches that oligomerize to form channels primarily comprised of alpha-helices [103]. Viroporins self-assemble and often demonstrate ion selectivity. Early on, hydrophobicity plots of the $6 \mathrm{~K}$ protein were noted to resemble those of other small virus proteins that modified membrane permeability [104]. Indeed, when the SINV 6K and TF genes are overexpressed alone in bacterial cells, they cause lysis $[15,105]$. Various studies have demonstrated that $6 \mathrm{~K}$ overexpression in bacterial cells also increases permeability to larger compounds such as the hydrophilic aminoglycoside hygromycin B (MW 527) [106-109]. Both synthetic peptides and recombinantly expressed full-length $6 \mathrm{~K}$ protein from RRV and Barmah Forest virus promote ion flow when added to planar membranes in vitro [56]. Enhanced ion flow across cell membranes was also observed when $6 \mathrm{~K}$ mRNAs capable of producing truncated TF products were injected into amphibian oocytes [110]. In planar lipid bilayers, the $6 \mathrm{~K}$ peptides demonstrate a selectivity towards cations, preferring monovalent to divalent cations. In oocytes, translated products increased cytosolic calcium levels and activated endogenous potassium chloride efflux. These expression system experiments support intrinsic ion channel activity of the $6 \mathrm{~K}$ protein. In contrast, for TF, the only data currently published demonstrates cell lysis upon overexpression in bacterial cells [15]. However, most of these experiments using the cloned $6 \mathrm{~K}$ gene would have likely translated TF truncation products. Therefore, additional studies looking independently at TF activity as an ion channel or pore would be informative.

In addition to demonstrating that a viral protein possesses stimulatory or intrinsic ion channel activity, the rigorous establishment of any viral protein as a functional viroporin uses evidence from appropriate stages during the virus life cycle [111]. A series of mutations and rescue attempts provide mounting evidence to support $6 \mathrm{~K}^{\prime} \mathrm{s}$ role in membrane permeabilization in standard cell culture models. The $6 \mathrm{~K}$ gene expressed from a viral genome, both with and without a translocation start signal to provide proper protein orientation, is the only major contributor to the membrane permeability changes observed in eukaryotic cells with normal intracellular trafficking [107]. Mutations both within the 6K transmembrane domain and at conserved bulky hydrophobic residues before the first transmembrane domain demonstrated that these regions are important for the membrane-permeabilizing phenotypes of $6 \mathrm{~K}[56,106]$. Specific residues in the $\mathrm{N}$-terminus and within the transmembrane domain affecting 
SINV 6K ion channel activity are also critical for the formation of intracellular virus structures and normal spike transport [112]. Although $6 \mathrm{~K}$ is sufficient to induce membrane permeability, the E1 transmembrane domain and residues immediately preceding it have also been shown to induce membrane permeability [113]. These data are the foundation for understanding the mechanism by which $6 \mathrm{~K}$ host ion permeability influences the outcome of a viral infection, and we can relate what is now known about $6 \mathrm{~K}$ to other viroporins to formulate guiding hypotheses.

Studies on other known viroporins highlight the mechanisms by which membrane permeability to ions influences the outcome of virus infection. The state of this field for viroporins that modulate intracellular ion homeostasis to affect pathogenesis and specifically promote virus release including influenza A virus M2 protein, hepatitis C virus p7 protein, coronavirus E protein, and HIV-1 Vpu protein has been reviewed in detail [103,114-116]. Here we mention briefly two proteins, M2 and p7, whose viroporin activity and mechanism of action in the virus lifecycle are well documented. The influenza A M2 protein is found in the virion and functions during both entry and virus release from the host cell. Infectious virus release is affected by M2 at the levels of $\mathrm{pH}$ control in the secretory system and direct alteration of membrane curvature [117-119]. Structures for the homotetrameric M2 proton channel are available [120-122]. The hepatitis $C$ virus $p 7$ protein forms a hexameric complex $[123,124]$. The $\mathrm{p} 7$ ion channel exhibits low selectivity and is linked to enhanced viral release, potentially at the stage of glycoprotein maturation inside the cell [124-127]. The influenza A M2 protein ion channel activity is inhibited by the commercially licensed adamantane compounds $[128,129]$. Various groups are pursuing $\mathrm{p} 7$ as a target for anti-hepatitis $\mathrm{C}$ virus therapy (see for example, www.biotron.com.au trials with the BIT225 compound, universal trial number U1111-1150-4404) [124,130]. Interestingly, M2 [131,132] and coronavirus E protein [133] are also palmitoylated, and palmitoylation is known to regulate cellular ion channel activities [134]. There is evidence that $6 \mathrm{~K}$ may be similar to these other viroporins. Defects observed in the SINV del-6K mutant, which does not produce normal $6 \mathrm{~K}$, can be partially rescued by expression of the full-length HIV-1 Vpu protein $[88,135]$. Substituting in only the Vpu transmembrane helix, or full-length $\mathrm{p} 7$, complements infectious particle production in infections without $6 \mathrm{~K}$ present, and this activity is inhibitor-dependent [112]. Studies on TF ion channel activity during infection are not available. These data support a mechanisms of action for $6 \mathrm{~K}$ that is similar to these other viroporins, where ion modulation ties directly to virus exit.

\section{TF as a Virulence Determinant in Animal Infections}

The TF protein in particular has been reported as a virulence factor by virtue of the fact that when it is missing, virulence is severely attenuated. This phenotype has been observed in several alphavirus infections. In SINV, 6K-only and TF mutants were used to infect a mouse model for neuropathogenesis [15]. All mice infected with TF mutants displayed reduced morbidity and increased survival compared to WT-infected mice. A similar outcome was seen with a CHIKV $\triangle 6 \mathrm{~K}$ virus, where symptoms were severely reduced in young infected mice, though the immune response was still adequate to protect the animal from future CHIKV challenge [136]. An RRV $\triangle 6 \mathrm{~K}$ strain is also suitable for vaccination and protection against challenge by other alphaviruses species in a mouse model [66]. These results may bring new relevance to the VEEV 6K deletions found to arise naturally during in vivo and tissue culture infections [44]. The deletions and point mutations reported all fell near or around the slip site required for TF production and tended to occur later in infection, which may function to modulate some important aspect of pathogenesis [44]. Those authors proposed that the slip site region could be a hotspot for recombination or template switching. This is consistent with the results of Kendra et al., showing mutations in $6 \mathrm{~K}$ that prevent TF frameshifting significantly reduce morbidity and mortality in the same New World alphavirus in mice infected via aerosol [53]. From these results, Kendra et al. hypothesized that TF may be needed for passage across the blood-brain barrier or neuroinvasiveness [53].

A related phenomenon is observed in the alphaviruses that infect fish. The fish alphaviruses are currently causing a severe burden on farmed salmonids in northern Europe and elsewhere [137]. 
The SAV $\Delta 6 \mathrm{~K}$ actually is not viable in cell culture and recombination can occur in both cell culture and in injected fish that yield infectious virus with at least partial $6 \mathrm{~K}$ sequences capable of causing pathology in subsequent hosts [43,46]. Indeed, when first isolating SAV, Weston and colleagues initially reported a small $6 \mathrm{~K}$ gene, but later found that $6 \mathrm{~K}$ simply had deletion variants $[138,139]$.

While no direct mechanism is known, mutations in the $6 \mathrm{~K}$ gene have also been reported in alphavirus strains causing outbreaks worldwide. Most lineage-defining mutations are found in the E1 and E2 glycoproteins; however, a few reports also identify mutations in the $6 \mathrm{~K}$ gene. No work has yet addressed TF production in circulating strains. In fish alphaviruses, there is little sequence variation in full SAV $6 \mathrm{~K}$ genes, but the isoleucine at position 7 is mutated to threonine [140]. In human epidemic strains there have also been a few $6 \mathrm{~K}$ variations reported. For example, the CHIKV strain in Mexico of the Caribbean lineage (Asian genotype) was found to sustain the 6K L20M mutation [141]. A set of isolates from Colombia contained the same mutation, as well as additional mutations in the C-terminus of $6 \mathrm{~K}$ that would also affect the TF sequence [142]. Interestingly, most subunit and virus-like particle vaccination approaches retain the $6 \mathrm{~K}$ gene sequence $[143,144]$. Although the reasons often given for this are that $\mathrm{E} 2$ requires $\mathrm{E} 1$ for proper folding and presentation on the cell surface, that is not always the case. Overall, variations in the $6 K$ and $T F$ gene sequences isolated from the environment may provide useful leads to researchers pursuing studies in TF virulence.

\section{Future Directions in 6K and TF Research}

Very little new information on the mechanism by which $6 \mathrm{~K}$ functions to affect budding or other viral processes has become available since the discovery of the TF protein, even though we now know that many of the budding phenotypes originally identified for $6 \mathrm{~K}$ are more likely attributable to TF. Neither $6 \mathrm{~K}$ nor TF are required for virus propagation in cell culture but the TF protein from several viruses has been shown to be a virulence factor. For this reason, it is of significant interest to uncover the independent functions of $6 \mathrm{~K}$ versus TF during an alphavirus infection. Below we discuss research areas that are critical to understanding the functional roles of the $6 \mathrm{~K}$ and TF proteins.

\subsection{How Does 6K Promote Budding from Inside the Cell?}

With $6 \mathrm{~K}$ residing primarily at interior cellular membranes (Figure 3), the questions about $6 \mathrm{~K}$ that need to be addressed center on its interactions with other proteins, viral and host, that serve to promote budding. Follow-up work on the interaction between $6 \mathrm{~K}$ and $\mathrm{E} 2$ is needed, since disruption of spike maturation can directly lead to reduced productive viral release. Currently available data can be interpreted to fit the $6 \mathrm{~K}$ spacer model, where $6 \mathrm{~K}$ is not required for trafficking the glycoproteins to the plasma membrane, but defects in spike folding or oligomerization efficiency in the absence of $6 \mathrm{~K}$ are inhibitory to effective budding. Secondly, it is of interest to determine whether $6 \mathrm{~K}$ interacts directly with host proteins. Such an interaction could serve to alleviate host cell stress responses that might prevent budding, or conversely promote an environment optimal for budding. Since $6 \mathrm{~K}$ mutants have increased cell-associated titer, studies to identify $6 \mathrm{~K}$ interaction partners might also provide insight into the differences in the location of budding observed between infected arthropod and mammalian host cells. Studies on $6 \mathrm{~K}$ can now be facilitated by using mutants in the frameshift slip site which do not produce TF. 
A. TF model

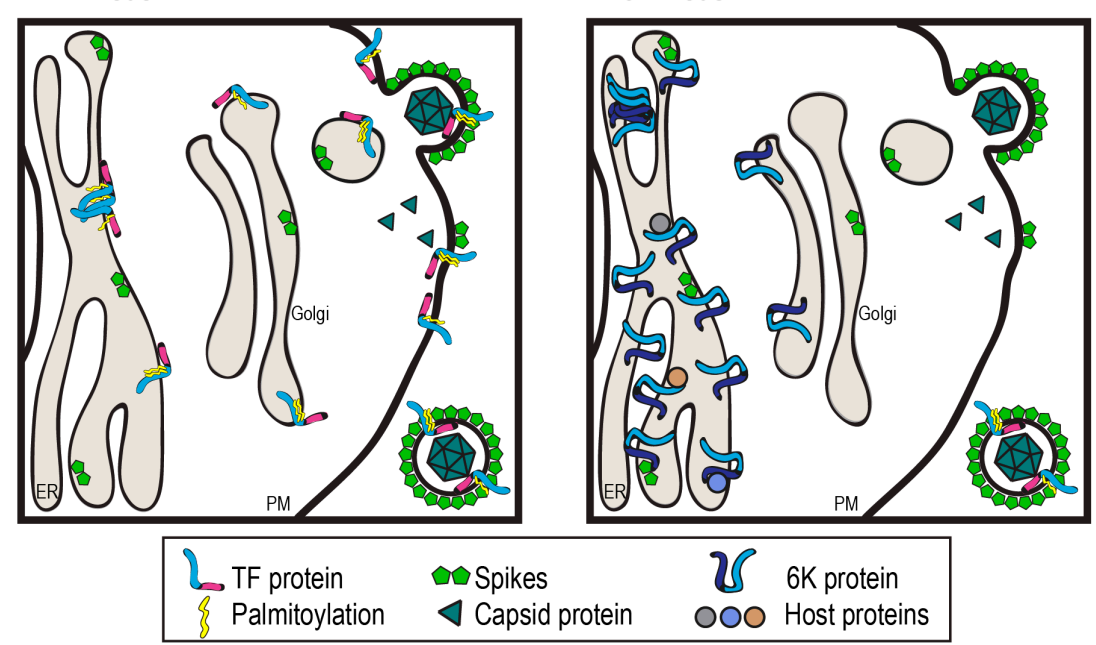

Figure 3. Model representing our current understanding of TF and 6K. (A) TF is less abundant than $6 \mathrm{~K}$. It is palmitoylated and traffics from the ER to the plasma membrane (PM) where it is budded into virions. TF may oligomerize and function as an ion channel. (B) $6 \mathrm{~K}$ is found concentrated at interior membranes where it likely interacts with the viral glycoproteins. The $6 \mathrm{~K}$ channel properties resulting from oligomerization probably affect the ER. Additionally, 6K may interact with host proteins.

\subsection{What Regulates TF Translation and Palmitoylation?}

While TF has been demonstrated to play a role in virus budding (Figure 3), its function in released virions remains unclear, and additional questions about the TF production and modification status remain unanswered. With regards to TF frameshifting levels, there is no quantitative data tracking TF levels within an infected cell population over time. Does the amount of TF increase linearly over time, or does a switch turn on TF in response to a specific cue? Plasmid-based frameshifting assays have allowed the dissection of the contributions that the RNA itself has to stimulate frameshifting, but we do not know if there are any proteinaceous factors that influence frameshifting. Understanding this mechanism in different alphaviruses has good promise for safe vaccine strain design and potentially the treatment of alphavirus diseases [53]. In addition to regulating the frameshifting rates by secondary structure elements, natural variants with losses of TF frameshifting elements may be another way to control infection in vivo $[44,46]$. Is this hotspot of recombination a way to control pathogenicity? As it is, we have limited data about TF levels and function in different host cell types, and in different alphavirus species, and no mechanistic information outside the standard lab cell lines and animal models.

The only known posttranslational modification on TF is its palmitoylation. It is intriguing that in WT, the TF protein is always modified, at least in SINV where the studies have been done. We do not, however, have any sense for whether the modification on TF is dynamic. Related to that, it is also unknown which cellular palmitoyl transferases actually modify TF. The palmitoylation studies on TF thus far have focused narrowly on vertebrate cell hosts, but it is of interest to characterize palmitoylation in mosquito cells as well. TF trafficking is linked to palmitoylation status, but there is also evidence that the transmembrane domain shared by 6K and TF may interact specifically with E2's transmembrane domain. What is the nature of such an interaction, and what impact does it have on not only protein trafficking to the plasma membrane, but also budding?

Studies focusing on TF alone are challenging without a TF-only virus. Constructing such a mutant is complicated by the need to ensure all the viral proteins in the polyprotein have the correct final membrane orientation. For example, attempting to generate a clone with the order CP-E3-E2-TF-E1 is not possible because the E1 ectodomain would be in the cytoplasm rather than the lumen. Also, expressing TF after E1 would result in a TF protein with its N-terminus in the cytoplasm 
rather than in the lumen. A clever strategy using inert linkers or artificial signal sequences is therefore needed to build this useful virus tool.

\subsection{What is the Structure and Oligomeric State of the 6K and TF Proteins?}

Our knowledge of the structure of $6 \mathrm{~K}$ and TF is based on secondary structure predictions and cleavage of the structural polyprotein. In order to determine how $6 \mathrm{~K}$ and TF each affect particle release, it is important to determine the structure of the individual proteins, their functional oligomeric state, and where and how TF is organized in the released virion. Knowing the structure of the individual proteins in the host and in the released virion would provide a structure-function link to identify the what and how of $6 \mathrm{~K}$ and TF function. No experimentally determined structures for these proteins exist, and neither has been resolved in whole virus [145-150]. Our view on their membrane topology is based mainly on the known topology of the pre-cleavage structural polyprotein, where the termini must be in the ER for signalase to cleave, and the hydrophobic properties of the primary sequence. The $6 \mathrm{~K}$ and TF proteins are translated with identical N-termini and unique C-termini. TF is palmitoylated at multiple cysteine residues in the $\mathrm{N}$-terminus. Though the $\mathrm{N}$-terminal cysteines are in both proteins, $6 \mathrm{~K}$ is not palmitoylated. The precise membrane topology of the C-terminus of $6 \mathrm{~K}$ is unknown. It likely is translated as a two-pass protein with both termini in the ER lumen and available for cleavage by signalase, but post-cleavage it has been proposed to adopt a Type I membrane protein (single pass) or hairpin conformation $[11,73,77,92,106]$. Kyte-Doolittle and other hydrophobicity profiles support two transmembrane domains in $6 \mathrm{~K}[43,56,88,106]$. However, the predicted transmembrane domains may represent a single integral membrane helix. If $6 \mathrm{~K}$ folds into a single membrane-spanning helix, its cysteine residues could reside in the membrane rather than in the cytoplasm, and this might explain why it is not palmitoylated on residues that are modified in TF. In comparison, even less is known regarding TF's conformation, and its final membrane conformation has broad implications for its function. Different conformations for the two proteins could explain why TF and not $6 \mathrm{~K}$ is palmitoylated on shared cysteine residues and how TF localizes to the plasma membrane in a palmitoylation-dependent manner in SINV [16].

The precise membrane insertion of small membrane proteins is often difficult to assess with confidence and there may be more than one correct answer, as seen for the coronavirus E protein. Evidence has been presented, suggesting that the coronavirus E protein adopts multiple membrane-spanning conformations, and a hairpin state [151-153]. These various orientations and different oligomeric states manifest clearly separable phenotypes [151,153]. Further study into the structure of the $6 \mathrm{~K}$ and TF proteins may reveal a similar case.

Questions of immediate interest regarding TF relate to its presence in the virion. Is its presence incidental to some unknown function it carries out near sites of budding within the originator host cell? Do the low levels of TF in the virion serve an important purpose? How are the low copy numbers of TF organized in the virion? It is not known if the population of virus particles is homogenous in its TF content, though it is generally assumed so. Mutants missing TF, or lacking palmitoylation, are known to differ from WT in gross morphology and thermolability $[13,16,64]$. This is useful to know because it may shed light on how TF is selectively incorporated into the virus particle. Since 6K has also been reported to incorporate into SINV particles [15], the isoform that is incorporated may differ between alphaviruses based on localization.

\subsection{Can We Target the Budding Proteins $6 \mathrm{~K}$ and TF for Antivirals?}

Very few antivirals on the market today are directed at virus escape. One well-known example is Tamiflu which blocks the neuraminidase activity required for influenza virus exit [154,155]. Viroporins often affect exit and have also been proposed as viable antiviral targets. In hepatitis $C$ virus, inhibitors targeting the viroporin protein $\mathrm{p} 7$ are currently being tested in human trials $[124,130]$. With the widespread references to $6 \mathrm{~K}^{\prime} \mathrm{s}$ role as a viroporin, both the $6 \mathrm{~K}$ and TF proteins represent interesting potential targets for antivirals inhibiting the alphavirus exit process. We know that the involvement of 
$6 \mathrm{~K}$ and TF in the spread of virus particles between permissive cells within an organism impacts disease severity. Preventing alphaviruses from exiting host cells and traversing to the next cell may therefore mitigate or prevent disease progression. More careful work is needed to demonstrate the importance of $6 \mathrm{~K}$ specifically (without the potential for generating TF truncations), and TF also, in ion transport. In particular, studies addressing the effects of modulating ion channel activity in infected cells on virus production are high priority. Despite feasibility as an effective antiviral strategy, antivirals against virus release are not in widespread use because the details involved in virus escape from infected host cells are not well understood. Understanding the mechanisms of action of $6 \mathrm{~K}$ and TF in escape could guide future efforts to fatally stall budding.

\section{Conclusions}

The story of $6 \mathrm{~K}$ and TF is a classic scientific paradigm shift. For 20 years, studies on $6 \mathrm{~K}$ were interpreted in the context of all the information available at the time, where $6 \mathrm{~K}$ was a small membrane protein involved in budding. When TF was discovered, the old literature had to be re-interpreted in the light of a new paradigm. The $6 \mathrm{~K}$ gene is translated into two proteins that have separate roles in budding. Now, we know that $6 \mathrm{~K}$ likely promotes virus release by its role inside the cell, including interactions with the glycoprotein spikes. The TF protein is present in virions and its function there remains unknown, but it is important for spread in an animal host. The road ahead is now populated with a new and exciting series of research questions whose answers will lead us to a better understanding of $6 \mathrm{~K}$ and TF as individual proteins, and ultimately a better picture of enveloped virus budding.

Acknowledgments: We thank Anthony Snyder, Tamanash Bhattacharya, Sara Jones, and Pranav Danthi for critical reading of this manuscript. We also thank Joyce Jose and Richard Kuhn for sharing unpublished work.

Conflicts of Interest: The authors declare no conflict of the interest.

\section{References}

1. Kuhn, R.J. Togaviridae. In Fields Virology; Knipe, D.M., Howley, P., Eds.; Lippincott Williams \& Wilkins: Philadelphia, PA, USA, 2013; Chapter 22, p. 2664.

2. Sokoloski, K.J.; Snyder, A.J.; Liu, N.H.; Hayes, C.A.; Mukhopadhyay, S.; Hardy, R.W. Encapsidation of Host-Derived Factors Correlates with Enhanced Infectivity of Sindbis Virus. J. Virol. 2013, 87, 12216-12226. [CrossRef] [PubMed]

3. Griffin, D.E. Alphaviruses. In Fields Virology; Howley, P., Knipe, D.M., Eds.; Lippincott Williams \& Wilkins: Philadelphia, PA, USA, 2013; Chapter 23, Volume 1, p. 2664.

4. Strauss, J.H.; Strauss, E.G. The alphaviruses: Gene expression, replication, and evolution. Microbiol. Rev. 1994, 58, 491-562. [PubMed]

5. Rupp, J.C.; Sokoloski, K.J.; Gebhart, N.N.; Hardy, R.W. Alphavirus RNA synthesis and non-structural protein functions. J. Gen. Virol. 2015, 96, 2483-2500. [CrossRef] [PubMed]

6. Fros, J.; Pijlman, G. Alphavirus Infection: Host Cell Shut-Off and Inhibition of Antiviral Responses. Viruses 2016, 8, 166. [CrossRef] [PubMed]

7. Garmashova, N.; Gorchakov, R.; Volkova, E.; Paessler, S.; Frolova, E.; Frolov, I. The Old World and New World Alphaviruses Use Different Virus-Specific Proteins for Induction of Transcriptional Shutoff. J. Virol. 2007, 81, 2472-2484. [CrossRef] [PubMed]

8. Atasheva, S.; Garmashova, N.; Frolov, I.; Frolova, E. Venezuelan Equine Encephalitis Virus Capsid Protein Inhibits Nuclear Import in Mammalian but not in Mosquito Cells. J. Virol. 2008, 82, 4028-4041. [CrossRef] [PubMed]

9. Akhrymuk, I.; Kulemzin, S.V.; Frolova, E.I. Evasion of the innate immune response: The Old World alphavirus nsP2 protein induces rapid degradation of Rpb1, a catalytic subunit of RNA polymerase II. J. Virol. 2012, 86, 7180-7191. [CrossRef] [PubMed]

10. Aliperti, G.; Schlesinger, M.J. Evidence for an autoprotease activity of Sindbis virus capsid protein. Virology 1978, 90, 366-369. [CrossRef] 
11. Melancon, P.; Garoff, H. Processing of the Semliki Forest virus structural polyprotein: Role of the capsid protease. J. Virol. 1987, 61, 1301-1309. [PubMed]

12. Hahn, C.S.; Strauss, J.H. Site-directed mutagenesis of the proposed catalytic amino acids of the Sindbis virus capsid protein autoprotease. J. Virol. 1990, 64, 3069-3073. [PubMed]

13. Gaedigk-Nitschko, K.; Ding, M.X.; Levy, M.A.; Schlesinger, M.J. Site-directed mutations in the Sindbis virus $6 \mathrm{~K}$ protein reveal sites for fatty acylation and the underacylated protein affects virus release and virion structure. Virology 1990, 175, 282-291. [CrossRef]

14. Firth, A.E.; Chung, B.Y.; Fleeton, M.N.; Atkins, J.F. Discovery of frameshifting in Alphavirus $6 \mathrm{~K}$ resolves a 20-year enigma. Virol. J. 2008, 5, 108. [CrossRef] [PubMed]

15. Snyder, J.E.; Kulcsar, K.A.; Schultz, K.L.W.; Riley, C.P.; Neary, J.T.; Marr, S.; Jose, J.; Griffin, D.E.; Kuhn, R.J. Functional characterization of the alphavirus TF protein. J. Virol. 2013, 87, 8511-8523. [CrossRef] [PubMed]

16. Ramsey, J.; Renzi, E.C.; Arnold, R.J.; Trinidad, J.C.; Mukhopadhyay, S. Palmitoylation of Sindbis Virus TF Protein Regulates Its Plasma Membrane Localization and Subsequent Incorporation into Virions. J. Virol. 2017, 91, e02000-16. [CrossRef] [PubMed]

17. Rice, C.M.; Strauss, J.H. Nucleotide sequence of the 26S mRNA of Sindbis virus and deduced sequence of the encoded virus structural proteins. Proc. Natl. Acad. Sci. USA 1981, 78, 2062-2066. [CrossRef] [PubMed]

18. Dalbey, R.E.; Lively, M.O.; Bron, S.; van Dijl, J.M. The chemistry and enzymology of the type I signal peptidases. Protein Sci. 1997, 6, 1129-1138. [CrossRef] [PubMed]

19. Mulvey, M.; Brown, D.T. Assembly of the Sindbis virus spike protein complex. Virology 1996, 219, $125-132$. [CrossRef] [PubMed]

20. Carleton, M.; Brown, D.T. Disulfide bridge-mediated folding of Sindbis virus glycoproteins. J. Virol. 1996, 70, 5541-5547. [PubMed]

21. Molinari, M.; Helenius, A. Glycoproteins form mixed disulphides with oxidoreductases during folding in living cells. Nature 1999, 402, 90-93. [CrossRef] [PubMed]

22. Molinari, M. Chaperone Selection During Glycoprotein Translocation into the Endoplasmic Reticulum. Science 2000, 288, 331-333. [CrossRef] [PubMed]

23. Parrott, M.M.; Sitarski, S.A.; Arnold, R.J.; Picton, L.K.; Hill, R.B.; Mukhopadhyay, S. Role of Conserved Cysteines in the Alphavirus E3 Protein. J. Virol. 2009, 83, 2584-2591. [CrossRef] [PubMed]

24. Mulvey, M.; Brown, D.T. Involvement of the molecular chaperone BiP in maturation of Sindbis virus envelope glycoproteins. J. Virol. 1995, 69, 1621-1627. [PubMed]

25. Martín, C.S.-S.; Liu, C.Y.; Kielian, M. Dealing with low pH: Entry and exit of alphaviruses and flaviviruses. Trends Microbiol. 2009, 17, 514-521. [CrossRef] [PubMed]

26. Jose, J.; Snyder, J.E.; Kuhn, R.J. A structural and functional perspective of alphavirus replication and assembly. Future Microbiol. 2009, 4, 837-856. [CrossRef] [PubMed]

27. Lobigs, M.; Zhao, H.X.; Garoff, H. Function of Semliki Forest virus E3 peptide in virus assembly: Replacement of E3 with an artificial signal peptide abolishes spike heterodimerization and surface expression of E1. J. Virol. 1990, 64, 4346-4355. [PubMed]

28. Zhang, X.; Fugère, M.; Day, R.; Kielian, M. Furin processing and proteolytic activation of Semliki Forest virus. J. Virol. 2003, 77, 2981-2989. [CrossRef] [PubMed]

29. Welsch, S.; Müller, B.; Kräusslich, H.-G. More than one door-Budding of enveloped viruses through cellular membranes. FEBS Lett. 2007, 581, 2089-2097. [CrossRef] [PubMed]

30. Votteler, J.; Sundquist, W.I. Virus Budding and the ESCRT Pathway. Cell Host Microbe 2013, 14, $232-241$. [CrossRef] [PubMed]

31. Taylor, G.M.; Hanson, P.I.; Kielian, M. Ubiquitin Depletion and Dominant-Negative VPS4 Inhibit Rhabdovirus Budding without Affecting Alphavirus Budding. J. Virol. 2007, 81, 13631-13639. [CrossRef] [PubMed]

32. Yondola, M.; Carter, C. Un-“ESCRT-"ed Budding. Viruses 2011, 3, 26-31. [CrossRef] [PubMed]

33. Wilkinson, T.A.; Tellinghuisen, T.L.; Kuhn, R.J.; Post, C.B. Association of Sindbis Virus Capsid Protein with Phospholipid Membranes and the E2 Glycoprotein: Implications for Alphavirus Assembly. Biochemistry 2005, 44, 2800-2810. [CrossRef] [PubMed]

34. Skoging, U.; Vihinen, M.; Nilsson, L.; Liljeström, P. Aromatic interactions define the binding of the alphavirus spike to its nucleocapsid. Structure 1996, 4, 519-529. [CrossRef] 
35. Lee, S.; Owen, K.E.; Choi, H.K.; Lee, H.; Lu, G.; Wengler, G.; Brown, D.T.; Rossmann, M.G.; Kuhn, R.J. Identification of a protein binding site on the surface of the alphavirus nucleocapsid and its implication in virus assembly. Structure 1996, 4, 531-541. [CrossRef]

36. Soonsawad, P.; Xing, L.; Milla, E.; Espinoza, J.M.; Kawano, M.; Marko, M.; Hsieh, C.; Furukawa, H.; Kawasaki, M.; Weerachatyanukul, W.; et al. Structural Evidence of Glycoprotein Assembly in Cellular Membrane Compartments prior to Alphavirus Budding. J. Virol. 2010, 84, 11145-11151. [CrossRef] [PubMed]

37. Jose, J.; Taylor, A.B.; Kuhn, R.J. Spatial and Temporal Analysis of Alphavirus Replication and Assembly in Mammalian and Mosquito Cells. mBio 2017, 8, e02294-16. [CrossRef] [PubMed]

38. Acheson, N.H.; Tamm, I. Replication of Semliki Forest virus: An electron microscopic study. Virology 1967, 32, 128-143. [CrossRef]

39. Miller, M.L.; Brown, D.T. Morphogenesis of Sindbis virus in three subclones of Aedes albopictus (mosquito) cells. J. Virol. 1992, 66, 4180-4190. [PubMed]

40. Forrester, N.L.; Palacios, G.; Tesh, R.B.; Savji, N.; Guzman, H.; Sherman, M.; Weaver, S.C.; Lipkin, W.I. Genome-Scale Phylogeny of the Alphavirus Genus Suggests a Marine Origin. J. Virol. 2012, 86, 2729-2738. [CrossRef] [PubMed]

41. Nasar, F.; Palacios, G.; Gorchakov, R.V.; Guzman, H.; Da Rosa, A.P.T.; Savji, N.; Popov, V.L.; Sherman, M.B.; Lipkin, W.I.; Tesh, R.B. Eilat virus, a unique alphavirus with host range restricted to insects by RNA replication. Proc. Natl. Acad. Sci. USA 2012, 109, 14622-14627. [CrossRef] [PubMed]

42. Hermanns, K.; Zirkel, F.; Kopp, A.; Marklewitz, M.; Rwego, I.B.; Estrada, A.; Gillespie, T.R.; Drosten, C.; Junglen, S. Discovery of a novel alphavirus related to Eilat virus. J. Gen. Virol. 2017, 98, 43-49. [CrossRef] [PubMed]

43. Guo, T.-C.; Johansson, D.X.; Haugland, Ø.; Liljeström, P.; Evensen, Ø. A 6K-Deletion Variant of Salmonid Alphavirus Is Non-Viable but Can Be Rescued through RNA Recombination. PLoS ONE 2014, 9, e100184. [CrossRef] [PubMed]

44. Forrester, N.L.; Guerbois, M.; Adams, A.P.; Liang, X.; Weaver, S.C. Analysis of Intrahost Variation in Venezuelan Equine Encephalitis Virus Reveals Repeated Deletions in the 6-Kilodalton Protein Gene. J. Virol. 2011, 85, 8709-8717. [CrossRef] [PubMed]

45. Petterson, E.; Stormoen, M.; Evensen, O.; Mikalsen, A.B.; Haugland, O. Natural infection of Atlantic salmon (Salmo salar L.) with salmonid alphavirus 3 (SAV3) generates numerous viral deletion mutants. J. Gen. Virol. 2013, 94, 1945-1954. [CrossRef] [PubMed]

46. Petterson, E.; Guo, T.-C.; Evensen, Ø.; Mikalsen, A.B. Experimental piscine alphavirus RNA recombination in vivo yields both viable virus and defective viral RNA. Sci. Rep. 2016, 1-10. [CrossRef] [PubMed]

47. Jacks, T.; Power, M.D.; Masiarz, F.R.; Luciw, P.A.; Barr, P.J.; Varmus, H.E. Characterization of ribosomal frameshifting in HIV-1 Gag-Pol expression. Nature 1988, 331, 280-283. [CrossRef] [PubMed]

48. Jacks, T.; Madhani, H.D.; Masiarz, F.R.; Varmus, H.E. Signals for ribosomal frameshifting in the Rous sarcoma virus Gag-Pol region. Cell 1988, 55, 447-458. [CrossRef]

49. Jacks, T.; Varmus, H.E. Expression of the Rous sarcoma virus Pol gene by ribosomal frameshifting. Science 1985, 230, 1237-1242. [CrossRef] [PubMed]

50. Dinman, J.D. Mechanisms and implications of programmed translational frameshifting. WIREs RNA 2012, 3, 661-673. [CrossRef] [PubMed]

51. Atkins, J.F.; Loughran, G.; Bhatt, P.R.; Firth, A.E.; Baranov, P.V. Ribosomal frameshifting and transcriptional slippage: From genetic steganography and cryptography to adventitious use. Nucleic Acids Res. 2016, 44, 7007-7078. [CrossRef] [PubMed]

52. Chung, B.Y.W.; Firth, A.E.; Atkins, J.F. Frameshifting in Alphaviruses: A Diversity of 3' Stimulatory Structures. J. Mol. Biol. 2010, 397, 448-456. [CrossRef] [PubMed]

53. Kendra, J.A.; de la Fuente, C.; Brahms, A.; Woodson, C.; Bell, T.M.; Chen, B.; Khan, Y.A.; Jacobs, J.L.; Kehn-Hall, K.; Dinman, J.D. Ablation of Programmed -1 Ribosomal Frameshifting in Venezuelan Equine Encephalitis Virus Results in Attenuated Neuropathogenicity. J. Virol. 2017, 91, e01766-16. [CrossRef] [PubMed]

54. Welch, W.J.; Sefton, B.M. Two small virus-specific polypeptides are produced during infection with Sindbis virus. J. Virol. 1979, 29, 1186-1195. [PubMed] 
55. Gaedigk-Nitschko, K.; Schlesinger, M.J. Site-directed mutations in Sindbis virus E2 glycoprotein's cytoplasmic domain and the $6 \mathrm{~K}$ protein lead to similar defects in virus assembly and budding. Virology 1991, 183, 206-214. [CrossRef]

56. Melton, J.V.; Ewart, G.D.; Weir, R.C.; Board, P.G.; Lee, E.; Gage, P.W. Alphavirus 6K Proteins Form Ion Channels. J. Biol. Chem. 2002, 277, 46923-46931. [CrossRef] [PubMed]

57. International Committee on the Taxonomy of Viruses. Available online: https://talk.ictvonline.org/ (accessed on 26 May 2017).

58. Clark, K.; Karsch-Mizrachi, I.; Lipman, D.J.; Ostell, J.; Sayers, E.W. GenBank. Nucleic Acids Res. 2016, 44, D67-D72. [CrossRef] [PubMed]

59. Heringa, J. Two strategies for sequence comparison: Profile-preprocessed and secondary structure-induced multiple alignment. Comput. Chem. 1999, 23, 341-364. [CrossRef]

60. Simossis, V.A.; Heringa, J. The PRALINE online server: Optimising progressive multiple alignment on the web. Comput. Biol. Chem. 2003, 27, 511-519. [CrossRef] [PubMed]

61. Simossis, V.A.; Kleinjung, J.; Heringa, J. Homology-extended sequence alignment. Nucleic Acids Res. 2005, 33, 816-824. [CrossRef] [PubMed]

62. Simossis, V.A.; Heringa, J. PRALINE: A multiple sequence alignment toolbox that integrates homology-extended and secondary structure information. Nucleic Acids Res. 2005, 33, W289-W294. [CrossRef] [PubMed]

63. Liljeström, P.; Lusa, S.; Huylebroeck, D.; Garoff, H. In vitro mutagenesis of a full-length cDNA clone of Semliki Forest virus: The small 6000-molecular-weight membrane protein modulates virus release. J. Virol. 1991, 65, 4107-4113. [PubMed]

64. Loewy, A.; Smyth, J.; von Bonsdorff, C.H.; Liljeström, P.; Schlesinger, M.J. The 6-kilodalton membrane protein of Semliki Forest virus is involved in the budding process. J. Virol. 1995, 69, 469-475. [PubMed]

65. Ivanova, L.; Lustig, S.; Schlesinger, M.J. A pseudo-revertant of a Sindbis virus 6K protein mutant, which corrects for aberrant particle formation, contains two new mutations that map to the ectodomain of the E2 glycoprotein. Virology 1995, 206, 1027-1034. [CrossRef] [PubMed]

66. Taylor, A.; Melton, J.V.; Herrero, L.J.; Thaa, B.; Karo-Astover, L.; Gage, P.W.; Nelson, M.A.; Sheng, K.-C.; Lidbury, B.A.; Ewart, G.D.; et al. Effects of an in-frame deletion of the $6 \mathrm{~K}$ gene locus from the genome of Ross River virus. J. Virol. 2016, 90, 4150-4159. [CrossRef] [PubMed]

67. Bonatti, S.; Blobel, G. Absence of a cleavable signal sequence in Sindbis virus glycoprotein PE2. J. Biol. Chem. 1979, 254, 12261-12264. [PubMed]

68. Bonatti, S.; Migliaccio, G.; Blobel, G.; Walter, P. Role of signal recognition particle in the membrane assembly of Sindbis viral glycoproteins. Eur. J. Biochem. 1984, 140, 499-502. [CrossRef] [PubMed]

69. Garoff, H.; Huylebroeck, D.; Robinson, A.; Tillman, U.; Liljeström, P. The signal sequence of the p62 protein of Semliki Forest virus is involved in initiation but not in completing chain translocation. J. Cell Biol. 1990, 111, 867-876. [CrossRef] [PubMed]

70. Burge, B.W.; Strauss, J.H. Glycopeptides of the membrane glycoprotein of Sindbis virus. J. Mol. Biol. 1970, 47, 449-466. [CrossRef]

71. Rice, C.M.; Bell, J.R.; Hunkapiller, M.W.; Strauss, E.G.; Strauss, J.H. Isolation and characterization of the hydrophobic $\mathrm{COOH}$-terminal domains of the sindbis virion glycoproteins. J. Mol. Biol. 1982, 154, 355-378. [CrossRef]

72. Welch, W.J.; Sefton, B.M. Characterization of a small, nonstructural viral polypeptide present late during infection of BHK cells by Semliki Forest virus. J. Virol. 1980, 33, 230-237. [PubMed]

73. Welch, W.J.; Sefton, B.M.; Esch, F.S. Amino-terminal sequence analysis of alphavirus polypeptides. J. Virol. 1981, 38, 968-972. [PubMed]

74. Rice, C.M.; Strauss, J.H. Synthesis, cleavage and sequence analysis of DNA complementary to the $26 \mathrm{~S}$ messenger RNA of Sindbis virus. J. Mol. Biol. 1981, 150, 315-340. [CrossRef]

75. Hashimoto, K.; Erdei, S.; Keränen, S.; Saraste, J.; Kaariainen, L. Evidence for a separate signal sequence for the carboxy-terminal envelope glycoprotein E1 of Semliki forest virus. J. Virol. 1981, 38, 34-40. [PubMed]

76. Melancon, P.; Garoff, H. Reinitiation of translocation in the Semliki Forest virus structural polyprotein: Identification of the signal for the E1 glycoprotein. EMBO J. 1986, 5, 1551-1560. [PubMed]

77. Liljeström, P.; Garoff, H. Internally located cleavable signal sequences direct the formation of Semliki Forest virus membrane proteins from a polyprotein precursor. J. Virol. 1991, 65, 147-154. [PubMed] 
78. Migliaccio, G.; Pascale, M.C.; Leone, A.; Bonatti, S. Biosynthesis, membrane translocation, and surface expression of Sindbis virus E1 glycoprotein. Exp. Cell Res. 1989, 185, 203-216. [CrossRef]

79. Metz, S.W.; Geertsema, C.; Martina, B.E.; Andrade, P.; Heldens, J.G.; Van Oers, M.M.; Goldbach, R.W.; Vlak, J.M.; Pijlman, G.P. Functional processing and secretion of Chikungunya virus E1 and E2 glycoproteins in insect cells. Virol. J. 2011, 8, 353. [CrossRef] [PubMed]

80. Schmidt, M.F.; Bracha, M.; Schlesinger, M.J. Evidence for covalent attachment of fatty acids to Sindbis virus glycoproteins. Proc. Natl. Acad. Sci. USA 1979, 76, 1687-1691. [CrossRef] [PubMed]

81. Schmidt, M.F.; Schlesinger, M.J. Fatty acid binding to vesicular stomatitis virus glycoprotein: A new type of post-translational modification of the viral glycoprotein. Cell 1979, 17, 813-819. [CrossRef]

82. Schmidt, M.F. Acylation of viral spike glycoproteins: A feature of enveloped RNA viruses. Virology 1982, 116, 327-338. [CrossRef]

83. Schmidt, M.; Schmidt, M.F.; Rott, R. Chemical identification of cysteine as palmitoylation site in a transmembrane protein (Semliki Forest virus E1). J. Biol. Chem. 1988, 263, 18635-18639. [PubMed]

84. Ivanova, L.; Schlesinger, M.J. Site-directed mutations in the Sindbis virus E2 glycoprotein identify palmitoylation sites and affect virus budding. J. Virol. 1993, 67, 2546-2551. [PubMed]

85. Ryan, C.; Ivanova, L.; Schlesinger, M.J. Effects of Site-Directed Mutations of Transmembrane Cysteines in Sindbis Virus E1 and E2 Glycoproteins on Palmitylation and Virus Replication. Virology 1998, 249, 62-67. [CrossRef] [PubMed]

86. Gaedigk-Nitschko, K.; Schlesinger, M.J. The Sindbis virus $6 \mathrm{~K}$ protein can be detected in virions and is acylated with fatty acids. Virology 1990, 175, 274-281. [CrossRef]

87. McInerney, G.M.; Smit, J.M.; Liljeström, P.; Wilschut, J. Semliki Forest virus produced in the absence of the $6 \mathrm{~K}$ protein has an altered spike structure as revealed by decreased membrane fusion capacity. Virology 2004, 325, 200-206. [CrossRef] [PubMed]

88. Sanz, M.A.; Carrasco, L. Sindbis virus variant with a deletion in the $6 \mathrm{~K}$ gene shows defects in glycoprotein processing and trafficking: Lack of complementation by a wild-type $6 \mathrm{~K}$ gene in trans. J. Virol. 2001, 75, 7778-7784. [CrossRef] [PubMed]

89. Metz, S.W.; Feenstra, F.; Villoing, S.; van Hulten, M.C.; van Lent, J.W.; Koumans, J.; Vlak, J.M.; Pijlman, G.P. Low Temperature-Dependent Salmonid Alphavirus Glycoprotein Processing and Recombinant Virus-Like Particle Formation. PLoS ONE 2011, 6, e25816. [CrossRef] [PubMed]

90. Hikke, M.C.; Braaen, S.; Villoing, S.; Hodneland, K.; Geertsema, C.; Verhagen, L.; Frost, P.; Vlak, J.M.; Rimstad, E.; Pijlman, G.P. Salmonid alphavirus glycoprotein E2 requires low temperature and E1 for virion formation and induction of protective immunity. Vaccine 2014, 32, 6206-6212. [CrossRef] [PubMed]

91. Rice, C.M.; Levis, R.; Strauss, J.H.; Huang, H.V. Production of infectious RNA transcripts from Sindbis virus cDNA clones: Mapping of lethal mutations, rescue of a temperature-sensitive marker, and in vitro mutagenesis to generate defined mutants. J. Virol. 1987, 61, 3809-3819. [PubMed]

92. Ivanova, L.; Le, L.; Schlesinger, M.J. Characterization of revertants of a Sindbis virus $6 \mathrm{~K}$ gene mutant that affects proteolytic processing and virus assembly. Virus Res. 1995, 39, 165-179. [CrossRef]

93. Strauss, E.G.; Birdwell, C.R.; Lenches, E.M.; Staples, S.E.; Strauss, J.H. Mutants of Sindbis virus II. Characterization of a maturation-defective mutant, ts103. Virology 1977, 82, 122-149. [CrossRef]

94. Lusa, S.; Garoff, H.; Liljeström, P. Fate of the 6K membrane protein of Semliki Forest virus during virus assembly. Virology 1991, 185, 843-846. [CrossRef]

95. Wu, D.; Xu, W.; Jiao, R.; Ding, M.; Zhai, Z. The relationship of Sindbis virus assembly and the viral protein $6 \mathrm{~K}$ with intermediate filaments. Acta Microbiol. Sin. 1990, 3, 417-421.

96. Yao, J.S.; Strauss, E.G.; Strauss, J.H. Interactions between PE2, E1, and 6K required for assembly of alphaviruses studied with chimeric viruses. J. Virol. 1996, 70, 7910-7920. [PubMed]

97. Snyder, A.J.; Sokoloski, K.J.; Mukhopadhyay, S. Mutating conserved cysteines in the alphavirus E2 glycoprotein causes virus-specific assembly defects. J. Virol. 2012, 86, 3100-3111. [CrossRef] [PubMed]

98. Snyder, A.J.; Mukhopadhyay, S. The Alphavirus E3 Glycoprotein Functions in a Clade-Specific Manner. J. Virol. 2012, 86, 13609-13620. [CrossRef] [PubMed]

99. Strauss, E.G.; Lenches, E.M.; Strauss, J.H. Molecular Genetic Evidence that the Hydrophobic Anchors of Glycoproteins E2 and E1 Interact during Assembly of Alphaviruses. J. Virol. 2002, 76, 10188-10194. [CrossRef] 
100. London, S.D.; Schmaljohn, A.L.; Dalrymple, J.M.; Rice, C.M. Infectious enveloped RNA virus antigenic chimeras. Proc. Natl. Acad. Sci. USA 1992, 89, 207-211. [CrossRef] [PubMed]

101. Schlesinger, M.J.; London, S.D.; Ryan, C. An in-frame insertion into the Sindbis virus $6 K$ gene leads to defective proteolytic processing of the virus glycoproteins, a trans-dominant negative inhibition of normal virus formation, and interference in virus shut off of host-cell protein synthesis. Virology 1993, 193, 424-432. [CrossRef] [PubMed]

102. Fischer, W.B.; Krüger, J. Viral Channel-Forming Proteins. Int. Rev. Cell Mol. Biol. 2009, 275, 35-63. [PubMed]

103. Martinez-Gil, L.; Mingarro, I. Viroporins, Examples of the Two-Stage Membrane Protein Folding Model. Viruses 2015, 7, 3462-3482. [CrossRef] [PubMed]

104. Carrasco, L. Modification of membrane permeability by animal viruses. Adv. Virus Res. 1995. [CrossRef]

105. Sanz, M.A.; Pérez, L.; Carrasco, L. Semliki Forest virus 6 K protein modifies membrane permeability after inducible expression in Escherichia coli cells. J. Biol. Chem. 1994, 269, 12106-12110. [PubMed]

106. Sanz, M.A.; Madan, V.; Carrasco, L.; Nieva, J.L. Interfacial domains in Sindbis virus 6K protein. Detection and functional characterization. J. Biol. Chem. 2003, 278, 2051-2057. [CrossRef] [PubMed]

107. Madan, V.; Sanz, M.A.; Carrasco, L. Requirement of the vesicular system for membrane permeabilization by Sindbis virus. Virology 2005, 332, 307-315. [CrossRef] [PubMed]

108. Madan, V.; de García, M.J.; Sanz, M.A.; Carrasco, L. Viroporin activity of murine hepatitis virus E protein. FEBS Lett. 2005, 579, 3607-3612. [CrossRef] [PubMed]

109. Madan, V.; Redondo, N.; Carrasco, L. Cell permeabilization by poliovirus 2B viroporin triggers bystander permeabilization in neighbouring cells through a mechanism involving gap junctions. Cell. Microbiol. 2010, 12, 1144-1157. [CrossRef] [PubMed]

110. Antoine, A.-F.; Montpellier, C.; Cailliau, K.; Browaeys-Poly, E.; Vilain, J.-P.; Dubuisson, J. The Alphavirus 6K Protein Activates Endogenous Ionic Conductances when Expressed in Xenopus Oocytes. J. Membr. Biol. 2007, 215, 37-48. [CrossRef] [PubMed]

111. Kelly, M.L.; Cook, J.A.; Brown-Augsburger, P.; Heinz, B.A.; Smith, M.C.; Pinto, L.H. Demonstrating the intrinsic ion channel activity of virally encoded proteins. FEBS Lett. 2003, 552, 61-67. [CrossRef]

112. Jose, J.; Kuhn, R.J. Purdue University, West Lafayette, IN, USA. Personal communication, 2017.

113. Nieva, J.L.; Sanz, M.A.; Carrasco, L. Membrane-permeabilizing motif in Semliki forest virus E1 glycoprotein. FEBS Lett. 2004, 576, 417-422. [CrossRef] [PubMed]

114. Guo, H.-C.; Jin, Y.; Zhi, X.-Y.; Yan, D.; Sun, S.-Q. NLRP3 Inflammasome Activation by Viroporins of Animal Viruses. Viruses 2015, 7, 3380-3391. [CrossRef] [PubMed]

115. Hyser, J.M.; Estes, M.K. Pathophysiological Consequences of Calcium-Conducting Viroporins. Annu. Rev. Virol. 2015, 2, 473-496. [CrossRef] [PubMed]

116. Fung, T.; Torres, J.; Liu, D. The Emerging Roles of Viroporins in ER Stress Response and Autophagy Induction during Virus Infection. Viruses 2015, 7, 2834-2857. [CrossRef] [PubMed]

117. Rossman, J.S.; Jing, X.; Leser, G.P.; Balannik, V.; Pinto, L.H.; Lamb, R.A. Influenza Virus M2 Ion Channel Protein Is Necessary for Filamentous Virion Formation. J. Virol. 2010, 84, 5078-5088. [CrossRef] [PubMed]

118. Rossman, J.S.; Jing, X.; Leser, G.P.; Lamb, R.A. Influenza Virus M2 Protein Mediates ESCRT-Independent Membrane Scission. Cell 2010, 142, 902-913. [CrossRef] [PubMed]

119. Rossman, J.S.; Lamb, R.A. Influenza virus assembly and budding. Virology 2011, 411, 229-236. [CrossRef] [PubMed]

120. Stouffer, A.L.; Acharya, R.; Salom, D.; Levine, A.S.; di Costanzo, L.; Soto, C.S.; Tereshko, V.; Nanda, V.; Stayrook, S.; DeGrado, W.F. Structural basis for the function and inhibition of an influenza virus proton channel. Nature 2008, 451, 596-599. [CrossRef] [PubMed]

121. Schnell, J.R.; Chou, J.J. Structure and mechanism of the M2 proton channel of influenza a virus. Nature 2008, 451, 591-595. [CrossRef] [PubMed]

122. Cady, S.D.; Mishanina, T.V.; Hong, M. Structure of amantadine-bound M2 transmembrane peptide of influenza A in lipid bilayers from magic-angle-spinning solid-state NMR: The role of Ser31 in amantadine binding. J. Mol. Biol. 2009, 385, 1127-1141. [CrossRef] [PubMed]

123. Luik, P.; Chew, C.; Aittoniemi, J.; Chang, J.; Wentworth, P.; Dwek, R.A.; Biggin, P.C.; Vénien-Bryan, C.; Zitzmann, N. The 3-dimensional structure of a hepatitis $\mathrm{C}$ virus $\mathrm{p} 7$ ion channel by electron microscopy. Proc. Natl. Acad. Sci. USA 2009, 106, 12712-12716. [CrossRef] [PubMed] 
124. Madan, V.; Bartenschlager, R. Structural and Functional Properties of the Hepatitis C Virus p7 Viroporin. Viruses 2015, 7, 4461-4481. [CrossRef] [PubMed]

125. Wozniak, A.L.; Griffin, S.; Rowlands, D.; Harris, M.; Yi, M.; Lemon, S.M.; Weinman, S.A. Intracellular proton conductance of the hepatitis $\mathrm{C}$ virus $\mathrm{p} 7$ protein and its contribution to infectious virus production. PLoS Pathog. 2010, 6, e1001087. [CrossRef] [PubMed]

126. Atoom, A.M.; Jones, D.M.; Russell, R.S. Evidence suggesting that HCV p7 protects E2 glycoprotein from premature degradation during virus production. Virus Res. 2013, 176, 199-210. [CrossRef] [PubMed]

127. Scull, M.A.; Schneider, W.M.; Flatley, B.R.; Hayden, R.; Fung, C.; Jones, C.T.; van de Belt, M.; Penin, F.; Rice, C.M. The N-terminal Helical Region of the Hepatitis C Virus p7 Ion Channel Protein Is Critical for Infectious Virus Production. PLoS Pathog. 2015, 11, e1005297. [CrossRef] [PubMed]

128. Pielak, R.M.; Chou, J.J. Flu channel drug resistance: A tale of two sites. Protein Cell 2010, 1, $246-258$. [CrossRef] [PubMed]

129. Das, K.; Aramini, J.M.; Ma, L.-C.; Krug, R.M.; Arnold, E. Structures of influenza a proteins and insights into antiviral drug targets. Nat. Struct. Mol. Biol. 2010, 17, 530-538. [CrossRef] [PubMed]

130. Biotron Limited. Available online: www.biotron.com.au (accessed 26 May 2017). (Universal Trial Number U1111-1150-4404).

131. Sugrue, R.J.; Belshe, R.B.; Hay, A.J. Palmitoylation of the influenza a virus M2 protein. Virology 1990, 179, 51-56. [CrossRef]

132. Veit, M.; Klenk, H.D.; Kendal, A.; Rott, R. The M2 protein of influenza a virus is acylated. J. Gen. Virol. 1991, 72 Pt. 6, 1461-1465. [CrossRef] [PubMed]

133. Corse, E.; Machamer, C.E. The Cytoplasmic Tail of Infectious Bronchitis Virus E Protein Directs Golgi Targeting. J. Virol. 2002, 76, 1273-1284. [CrossRef] [PubMed]

134. Shipston, M.J. Ion channel regulation by protein S-acylation. J. Gen. Physiol. 2014, 143, 659-678. [CrossRef] [PubMed]

135. González, M.E.; Carrasco, L. Human immunodeficiency virus type 1 VPU protein affects Sindbis virus glycoprotein processing and enhances membrane permeabilization. Virology 2001, 279, 201-209. [CrossRef] [PubMed]

136. Hallengärd, D.; Kakoulidou, M.; Lulla, A.; Kümmerer, B.M.; Johansson, D.X.; Mutso, M.; Lulla, V.; Fazakerley, J.K.; Roques, P.; Le Grand, R.; et al. Novel attenuated Chikungunya vaccine candidates elicit protective immunity in C57BL/6 mice. J. Virol. 2014, 88, 2858-2866. [CrossRef] [PubMed]

137. Jansen, M.D.; Bang Jensen, B.; McLoughlin, M.F.; Rodger, H.D.; Taksdal, T.; Sindre, H.; Graham, D.A.; Lillehaug, A. The epidemiology of pancreas disease in salmonid aquaculture: A summary of the current state of knowledge. J. Fish Dis. 2016, 40, 141-155. [CrossRef] [PubMed]

138. Weston, J.H.; Welsh, M.D.; McLoughlin, M.F.; Todd, D. Salmon pancreas disease virus, an alphavirus infecting farmed Atlantic salmon, Salmo salar L. Virology 1999, 256, 188-195. [CrossRef] [PubMed]

139. Weston, J.; Villoing, S.; Bremont, M.; Castric, J.; Pfeffer, M.; Jewhurst, V.; McLoughlin, M.; Rodseth, O.; Christie, K.E.; Koumans, J.; et al. Comparison of Two Aquatic Alphaviruses, Salmon Pancreas Disease Virus and Sleeping Disease Virus, by Using Genome Sequence Analysis, Monoclonal Reactivity, and Cross-Infection. J. Virol. 2002, 76, 6155-6163. [CrossRef] [PubMed]

140. Jansen, M.D.; Gjerset, B.; Modahl, I.; Bohlin, J. Molecular epidemiology of salmonid alphavirus (SAV) subtype 3 in Norway. Virol. J. 2010, 7, 188. [CrossRef] [PubMed]

141. Díaz-Quiñonez, J.A.; Escobar-Escamilla, N.; Ortíz-Alcántara, J.; Vázquez-Pichardo, M.; Torres-Rodríguez, M.L.; Nuñez-León, A.; Torres-Longoria, B.; López-Martínez, I.; Ruiz-Matus, C.; Kuri-Morales, P.; et al. Identification of Asian genotype of chikungunya virus isolated in Mexico. Virus Genes 2016, 52, 127-129. [CrossRef] [PubMed]

142. Rodas, J.D.; Kautz, T.; Camacho, E.; Paternina, L.; Guzman, H.; Díaz, F.J.; Blanco, P.; Tesh, R.; Weaver, S.C. Genetic Characterization of Northwestern Colombian Chikungunya Virus Strains from the 2014-2015 Epidemic. Am. J. Trop. Med. Hyg. 2016, 95, 639-646. [CrossRef] [PubMed]

143. Erasmus, J.H.; Rossi, S.L.; Weaver, S.C. Development of Vaccines for Chikungunya Fever. J. Infect. Dis. 2016, 214, S488-S496. [CrossRef] [PubMed]

144. Weaver, S.C.; Osorio, J.E.; Livengood, J.A.; Chen, R.; Stinchcomb, D.T. Chikungunya virus and prospects for a vaccine. Expert Rev. Vaccines 2014, 11, 1087-1101. [CrossRef] [PubMed] 
145. Cheng, R.H.; Kuhn, R.J.; Olson, N.H.; Rossmann, M.G.; Choi, H.K.; Smith, T.J.; Baker, T.S. Nucleocapsid and glycoprotein organization in an enveloped virus. Cell 1995, 80, 621-630. [CrossRef]

146. Akahata, W.; Yang, Z.-Y.; Andersen, H.; Sun, S.; Holdaway, H.A.; Kong, W.-P.; Lewis, M.G.; Higgs, S.; Rossmann, M.G.; Rao, S.; et al. A virus-like particle vaccine for epidemic Chikungunya virus protects nonhuman primates against infection. Nat. Med. 2010, 16, 334-338. [CrossRef] [PubMed]

147. Kostyuchenko, V.A.; Jakana, J.; Liu, X.; Haddow, A.D.; Aung, M.; Weaver, S.C.; Chiu, W.; Lok, S.M. The Structure of Barmah Forest Virus as Revealed by Cryo-Electron Microscopy at a 6-Angstrom Resolution Has Detailed Transmembrane Protein Architecture and Interactions. J. Virol. 2011, 85, 9327-9333. [CrossRef] [PubMed]

148. Mukhopadhyay, S.; Zhang, W.; Gabler, S.; Chipman, P.R.; Strauss, E.G.; Strauss, J.H.; Baker, T.S.; Kuhn, R.J.; Rossmann, M.G. Mapping the Structure and Function of the E1 and E2 Glycoproteins in Alphaviruses. Structure 2006, 14, 63-73. [CrossRef] [PubMed]

149. Tang, J.; Jose, J.; Chipman, P.; Zhang, W.; Kuhn, R.J.; Baker, T.S. Molecular Links between the E2 Envelope Glycoprotein and Nucleocapsid Core in Sindbis Virus. J. Mol. Biol. 2011, 414, 442-459. [CrossRef] [PubMed]

150. Zhang, R.; Hryc, C.F.; Cong, Y.; Liu, X.; Jakana, J.; Gorchakov, R.; Baker, M.L.; Weaver, S.C.; Chiu, W. 4.4 $\AA$ cryo-EM structure of an enveloped alphavirus Venezuelan equine encephalitis virus. EMBO J. 2011, 30, 3854-3863. [CrossRef] [PubMed]

151. Ruch, T.R.; Machamer, C.E. A Single Polar Residue and Distinct Membrane Topologies Impact the Function of the Infectious Bronchitis Coronavirus E Protein. PLoS Pathog. 2012, 8, e1002674. [CrossRef] [PubMed]

152. Ruch, T.R.; Machamer, C.E. The Coronavirus E Protein: Assembly and Beyond. Viruses 2012, 4, $363-382$. [CrossRef] [PubMed]

153. Westerbeck, J.W.; Machamer, C.E. A Coronavirus E Protein Is Present in Two Distinct Pools with Different Effects on Assembly and the Secretory Pathway. J. Virol. 2015, 89, 9313-9323. [CrossRef] [PubMed]

154. Holodniy, M.; Kamali, A. Influenza treatment and prophylaxis with neuraminidase inhibitors: A review. Infect. Drug Resistance 2013, 6, 187-198. [CrossRef] [PubMed]

155. Von Itzstein, M.; Wu, W.Y.; Kok, G.B.; Pegg, M.S.; Dyason, J.C.; Jin, B.; Van Phan, T.; Smythe, M.L.; White, H.F.; Oliver, S.W. Rational design of potent sialidase-based inhibitors of influenza virus replication. Nature 1993, 363, 418-423. [CrossRef] [PubMed] 